\title{
Brood comb as a humidity buffer in honeybee nests
}

\author{
Michael B. Ellis • Sue W. Nicolson • Robin M. Crewe • \\ Vincent Dietemann
}

Received: 7 July 2009 /Revised: 6 February 2010 /Accepted: 6 February 2010 /Published online: 4 March 2010

(C) Springer-Verlag 2010

\begin{abstract}
Adverse environmental conditions can be evaded, tolerated or modified in order for an organism to survive. During their development, some insect larvae spin cocoons which, in addition to protecting their occupants against predators, modify microclimatic conditions, thus facilitating thermoregulation or reducing evaporative water loss. Silk cocoons are spun by honeybee (Apis mellifera) larvae and subsequently incorporated into the cell walls of the wax combs in which they develop. The accumulation of this hygroscopic silk in the thousands of cells used for brood rearing may significantly affect nest homeostasis by buffering humidity fluctuations. This study investigates the extent to which the comb may influence homeostasis by quantifying the hygroscopic capacity of the cocoons spun by honeybee larvae. When comb containing cocoons was placed at high humidity, it absorbed $11 \%$ of its own mass in water within 4 days. Newly drawn comb composed of hydrophobic wax and devoid of cocoons absorbed only $3 \%$ of its own mass. Therefore, the accumulation of cocoons in the comb may increase brood survivorship by maintaining a high and stable humidity in the cells.
\end{abstract}

Keywords Honeybee $\cdot$ Cocoon $\cdot$ Larvae $\cdot$ Humidity $\cdot$ Nest homeostasis

Communicated by Jürgen Heinze

M. B. Ellis $\cdot$ S. W. Nicolson $\cdot$ R. M. Crewe $\cdot$ V. Dietemann $(\triangle)$

Department of Zoology and Entomology, University of Pretoria,

Pretoria 0002, South Africa

e-mail: vincent.dietemann@alp.admin.ch

Present address:

V. Dietemann

Swiss Bee Research Centre,

Agroscope Liebefeld-Posieux Research Station ALP,

3003 Bern, Switzerland

\section{Introduction}

Many insects modify adverse microclimatic conditions rather than attempting to evade or tolerate them (Danks 2002). For example, the larvae of numerous insect species spin cocoons which, in addition to protecting their occupants against predators (Otto 1983), modify the local environment, thus facilitating thermoregulation or influencing water economy (Chauvin et al. 1979; Nowbahari and Thibout 1990; Lyon and Cartar 1996; Tagawa 1996). Although it is not obvious since they develop within the cells of their wax combs, honeybee (Apis mellifera) larvae also spin a silk cocoon. The silk is formed in the labial glands of larvae as an $\alpha$-helical fibroin of four strands which are coiled to form a silk thread (Rudall 1962). This structure enables hydrophobic residues to be shielded in core positions and polar, charged residues to fill non-core positions, thus making the silk hygroscopic. The silk is ultimately incorporated into the cell walls (Jay 1964). As an adult emerges from its cell, the cell is cleaned of debris before the queen lays another egg in it, but the silken cocoon remains. With successive generations, the cocoons therefore accumulate in a cell, eventually replacing the hydrophobic wax and causing the darkening of the comb (Hepburn and Kurstjens 1988). The accumulation of cocoons in the thousands of cells used for brood rearing may have significant implications at the colony level. The cocoons could affect nest homeostasis by buffering humidity fluctuations and thus passively influencing the regulation of this parameter (Human et al. 2006), as well as temperature (Klingner et al. 2005) in the nest. This study investigated the hygroscopic capacity of the cocoons spun by honeybee worker larvae. We hypothesised that an increase in silk content will cause an increase in the absorption capacity of the comb and could consequently influence nest homeostasis. 


\section{Materials and methods}

Nine pieces of light comb (i.e. containing no cocoons; Fig. 1a) and 20 pieces of dark comb (i.e. containing silken cocoons; Fig. 1b) were selected from different honeybee colonies (Apis mellifera scutellata). The light comb had been used for nectar storage before being cleaned by the workers and dark comb had been used for brood rearing. These were cut into blocks of $8 \times 8$ cells and then placed for 2 months into a desiccation chamber containing silica gel. The chamber was placed in an incubator set at $35^{\circ} \mathrm{C}$. The dry mass of desiccated combs was then determined with an analytical balance to $0.1 \mathrm{~g}$ (Mettler Toledo, AG64, Switzerland).

After the desiccation period four light and five dark combs remained in the chamber containing silica gel and the remaining combs were distributed into chambers with different humidities. Humidity within the brood nest is often found to be around 60\% RH (relative humidity; Ellis unpublished data; Human et al. 2006). For this reason, we placed five dark combs in a chamber containing a saturated salt solution of $\mathrm{NaNO}_{3}$, generating 60\% RH. With the presence of royal jelly or water in the cells, the cell's atmosphere is likely to be saturated with water vapour. To recreate these conditions, five light and ten dark combs were placed in a chamber containing a saturated salt solution of $\mathrm{K}_{2} \mathrm{Cr}_{2} \mathrm{O}_{7}$, generating $90 \% \mathrm{RH}$. Relative humidity in the three chambers was recorded with two Hygrochron iButton data loggers (DS1923, Dallas Semiconductor, USA) and a HOBO H8 data logger (Onset Computer Corporation, Pocasset, MA, USA). We thus confirmed that humidity was maintained at the required levels with little variation (silica gel, 1 $\pm 1.6 \% \mathrm{RH} ; \mathrm{NaNO}_{3}, 60 \pm 1.5 \%$ and $\mathrm{K}_{2} \mathrm{Cr}_{2} \mathrm{O}_{7}, 90 \pm 2.2 \% \mathrm{RH}$ ). The mass of each piece of comb was recorded every $12 \mathrm{~h}$; care being taken that they were not exposed to ambient humidity for longer than $20 \mathrm{~s}$. Microbial growth on the comb was observed after $120 \mathrm{~h}$ in the chamber with $90 \% \mathrm{RH}$ and therefore the measurements of mass after $96 \mathrm{~h}$ were not used.

Wohlgemuth (1957) and Büdel (1948) mentioned that high humidity favours the growth of microorganisms on the combs. In order to monitor the development of such growth, combs were photographed with a digital camera from a height of $35 \mathrm{~cm}$ under controlled lighting conditions before being placed in the humidity chambers. Combs were left in these chambers for 9 days after the last weighing (on
Fig. 1 a Light comb used for nectar storage and containing no larval cocoons. b Dark comb used for brood rearing and containing larval cocoons. c The dark comb shown in $\mathbf{b}$ after being left in $90 \%$ RH for 13 days showing microbial growth. d A cross-section through a dark comb after being left in $90 \% \mathrm{RH}$ for 13 days showing microbial growth on the coping but not on the cell walls
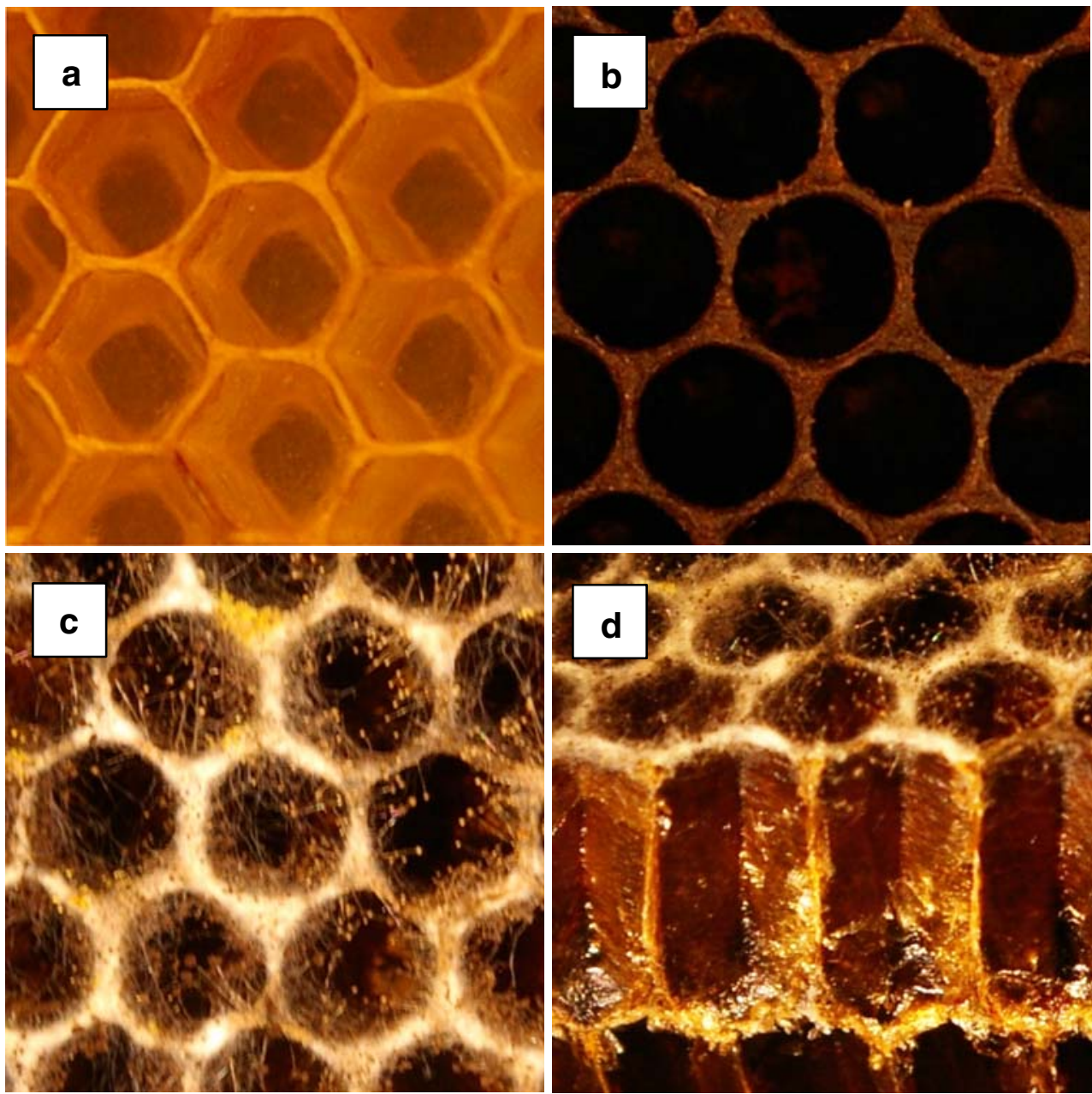
day 4) and were then photographed for a second time (on day 13). Since microbial growth modifies the appearance of the comb, the amount of growth was assessed by measuring the mean brightness of the picture of each piece of comb, before and after exposure to the various humidities, using a custom-designed image analysis software. The mean brightness was calculated over an area covering seven entire cells (Fig. 1).

Mann-Whitney $U$ tests were used to determine if differences existed between the water absorption capacity of light and dark comb and a Bonferroni adjustment was applied due to multiple comparisons. Sign tests were used to determine if differences existed between the brightness of combs photographed before and after exposure and a Mann-Whitney $U$ test was used to detect differences in brightness between light and dark comb. Data are presented as means \pm standard deviation.

\section{Results}

When dark comb containing cocoons was placed in a $90 \%$ RH chamber for $96 \mathrm{~h}$, it absorbed $11.1 \pm 3.2 \%(0.4 \pm 0.05 \mathrm{~g})$ of its own mass in water (Fig. 2). The dynamics of absorption fits an asymptotic curve and half of the water was absorbed within the first $30 \mathrm{~h}$. The decrease in absorption of the dark comb in $60 \% \mathrm{RH}$ between 36 and $48 \mathrm{~h}$ (Fig. 2) was due to the lid of the chamber not sealing properly, causing the humidity to drop from $60 \pm 1.5 \%$ to $24.0 \pm 0.51 \% \mathrm{RH}$. At $48 \mathrm{~h}$, the lid was again properly sealed and the comb resumed its increase in mass. After $96 \mathrm{~h}$, the dark comb had absorbed significantly less water at $1 \% \mathrm{RH}$ than at $60 \%$ or $90 \%$ RH (Mann-Whitney $U$ test, Bonferroni corrected alpha' $=0.025: N_{1 \%}=5, N_{60 \%}=5, Z=-2.6, p=$ $0.012<$ alpha'; $^{\prime} N_{1 \%}=5, N_{90 \%}=10, Z=-3.0, \quad p=0.003$ $<$ alpha'; Fig. 2). The amount of water absorbed by the dark comb at $1 \% \mathrm{RH}$ is not significantly different from that absorbed by the light comb at $1 \%$ RH (Mann-Whitney $U$ test; $N_{\text {dark }}=5, N_{\text {light }}=4, Z=-1.35, p=0.18$ ). When the light comb was placed at $90 \%$ RH for $96 \mathrm{~h}$, it absorbed $2.95 \pm$ $0.3 \%(0.06 \pm 0.01 \mathrm{~g})$ of its own mass in water which is significantly more than when at $1 \%$ RH (Mann-Whitney $U$ test, $N_{90 \%}=5, N_{1 \%}=4, Z=-2.45, p=0.025$ ) but significantly less than absorbed by the dark comb in $90 \%$ RH (MannWhitney $U$ test, $N_{\text {light }}=5, N_{\text {dark }}=10, Z=3.06, p=0.01$ ).

Photographs taken before treatment show that the light comb was approximately five times brighter than the dark comb (Mann-Whitney $U$ test, $N_{\text {light }}=9, N_{\text {dark }}=20, Z=4.24$, $p<0.001)$. There was no significant difference between the brightness of comb before and after 13 days of exposure to various humidities except for the dark comb placed in the $90 \%$ RH chamber (sign test, $N=10, Z=2.85, p<0.001$ ). These combs became brighter as a result of microbial growth on their coping (Fig. 1c and d).

\section{Discussion}

When placed in high humidity, dark brood comb absorbed a mean of $11 \%$ of the pre-desiccated comb mass of water. Microbial growth could be observed on these combs after $120 \mathrm{~h}$ exposure to $90 \% \mathrm{RH}$. In contrast, under the same condition, freshly produced wax only absorbed a mean of $3 \%$ of its mass in water and no microbial growth took place.
Fig. 2 Mean $( \pm \mathrm{SD})$ water sorption by light (no cocoons) and dark (with cocoons) comb when placed in $1 \%, 60 \%$ and $90 \% \mathrm{RH}$ for $96 \mathrm{~h}$, given as a percentage of comb mass. Data points of the $1 \%$ dark comb are offset by $1 \mathrm{~h}$ for visual clarity

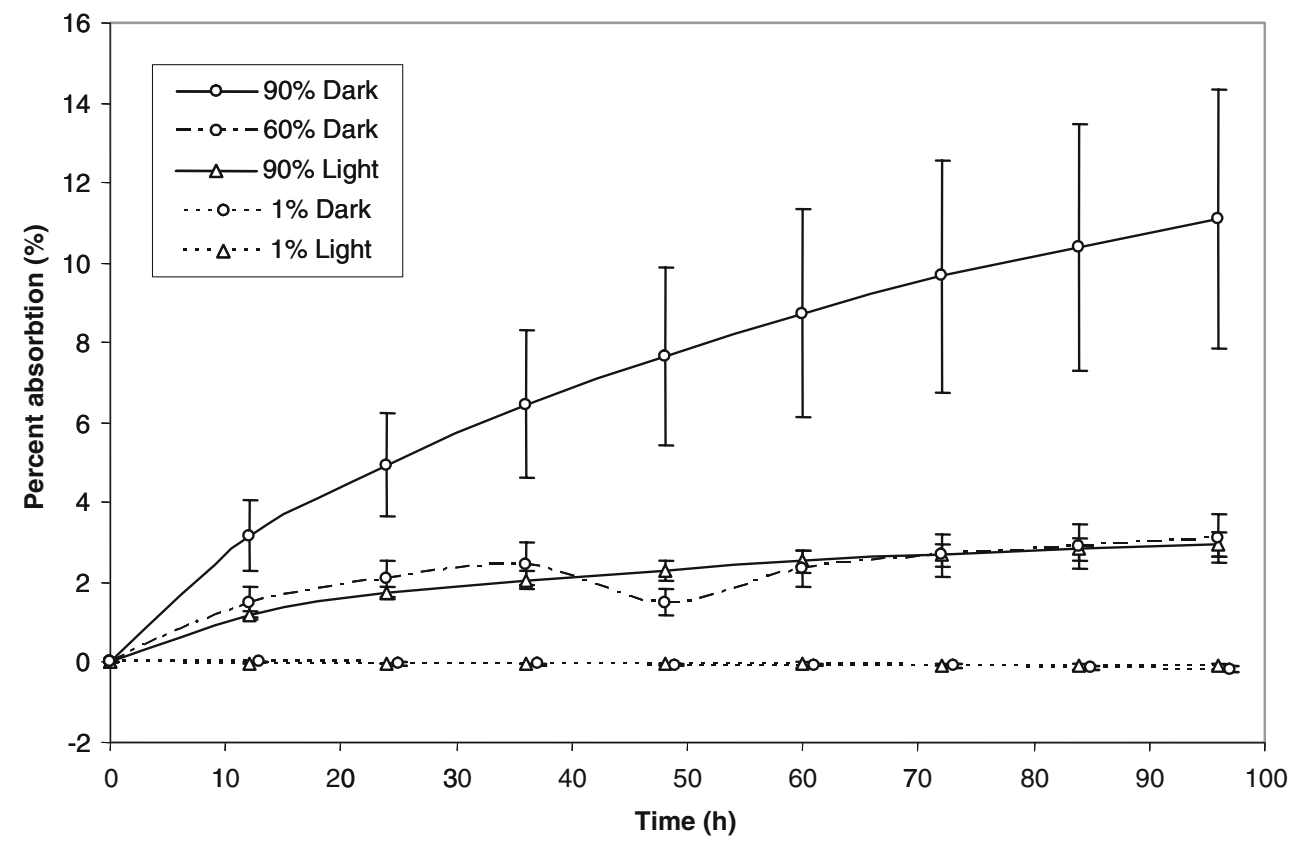


The high amount of water absorbed by dark combs suggests that the hygroscopic cocoons can act as water reservoirs. The large standard deviations in the mean mass observed for dark comb in $90 \%$ RH (Fig. 1) were not due to variation in absorption by individual combs over time but to consistent differences between individual combs. The disparity between these absorption curves is likely to be due to differences in age of the combs (i.e. number of cocoons) which was not controlled in our experiment. Our results also indicate that brood comb responds rapidly to changes in RH. When the $60 \%$ RH chamber did not seal properly, causing the RH to decrease for $12 \mathrm{~h}$, the comb lost $30 \%$ of its total absorbed water. These results suggest that the hygroscopic cocoons spun by honeybee larvae can rapidly release the absorbed water and can therefore have a substantial buffering effect on humidity within the hive. This may be the reason why Berry and Delaplane (2001) found better survivorship of brood reared in an older, darker comb. Light comb should have a low buffering capacity since it was shown to absorb only $3 \%$ of its mass in water. Although this is a relatively small amount of water, it is nonetheless unexpected that a comb composed of hydrophobic wax would absorb any water at all. It is possible that hygroscopic sugar or pollen residues which remained on the comb subsequent to cleaning by the workers could be responsible for the slight absorption.

The magnitude of the hygroscopic effect of brood comb in the context of a colony can be calculated from our results: the pieces of dark comb used contained 64 cells $(8 \times$ 8 ) and absorbed $0.4 \mathrm{~g}$ of water when placed at $90 \% \mathrm{RH}$. This implies that an established colony containing 14,140 to 23,000 brood cells (Otis and Wearing-Wilde 1992; McNally and Schneider 1992; Winston et al. 1981) lined with cocoons can store between 87.4 and $142.1 \mathrm{~g}$ of water. This amount is sufficient to saturate 2,215-3,603 1 of air at $35^{\circ} \mathrm{C}$. Given that the mean internal volume of a nest of $A$. mellifera scutellata is $44 \pm 141$ (Schneider and Blyther 1988), the quantity of water stored in the cocoons lining the cell walls is largely sufficient to maintain the hive atmosphere at high humidity.

High humidity of the nest atmosphere is, however, not beneficial to honeybees since it would prevent nectar evaporation during the honey ripening process (Reinhardt 1939) and favours the growth of microorganisms on the comb (Wohlgemuth 1957; Büdel 1948). This is consistent with our observation of microbial growth on the brood comb when it is exposed to high humidity for more than 4 days. Microbial growth took place extensively on the copings of the cells, whereas little growth was observed within the cells (Fig. 1d). Absence of growth within the cell is likely to be linked to the composition of the cell wall. Since the coping appears to be a good substrate for microbial growth, high humidity in the hive atmosphere is detrimental to colony hygiene. Fanning by honeybee workers, which expels damp air and replaces it with drier ambient air, is seemingly important in preventing this microbial growth and facilitating the evaporation of nectar (Ellis et al. 2008). This is consistent with humidity measured by Human et al. (2006) between brood combs which varied from approximately $40 \%$ to $60 \% \mathrm{RH}$; no growth was observed in our experiment at such humidity levels.

Growth does not take place on the cell walls even at $90 \%$ RH (Fig. 1d), and high humidity could therefore be maintained within the cell for optimal brood development. Indeed, Doull (1976) showed that brood requires a relative humidity of between $90 \%$ and $95 \%$ in order to hatch successfully. Such a microclimate within the cells would have no adverse effects on colony hygiene or nectar processing.

Exchange of air between the cell and hive atmosphere would decrease the cell's humidity due to the hive atmosphere being drier than the cell. This could occur passively through the cell opening or actively as a worker enters the cells to care for the brood. A worker's body is approximately the same volume as a cell and would thus expel most of the air from the cell as it enters; this air would subsequently be replaced from the hive atmosphere as the worker exits the cell. Several factors could, however, ensure the persistence or the fast recovery of high humidity within the cells. Workers are known to spread water (when the temperature is above $32^{\circ} \mathrm{C}$ ) onto the interior surfaces of brood cells, thereby increasing the water vapour within the cell (Lindauer 1954). In addition, larvae and developing pupae release water through cuticular and respiratory evaporation. Furthermore, the internal surface area of a cell is approximately $235 \mathrm{~mm}^{2}$, in comparison to the outer coping of the cell with a surface area of $2.1 \mathrm{~mm}^{2}$ (calculated from Hepburn 1986). This means that there is a substantially larger surface area from which water can directly evaporate from the comb structure into the cell atmosphere compared to the relatively small surface of the coping that is directly exposed to the nest atmosphere. The coping is constructed from wax and propolis (Ribbands 1953) which further reduces evaporation directly from this surface. The jelly provided to the larvae as food has high water content (e.g. Dietz and Haydak 1971) and may generate high RH in the cell. In contrast, eggs are placed in cells which do not contain jelly and if the evaporation of water from the cocoon-lined walls is insufficient to maintain high humidity, workers may need to increase humidity by other means in order to prevent desiccation of the eggs (Doull 1976). If cocoons indeed contribute to the regulation of nest humidity, recently established swarms with newly built comb should create different brood rearing conditions than colonies established in older nests. Indeed, freshly built comb 
composed of hygrophobic wax would not buffer humidity and workers would need to compensate for this lack.

We have shown that the honeybee brood comb containing cocoons absorbs a large amount of water and can release it when humidity decreases. Fanning by workers could ensure the hive atmosphere remains within a humidity range that is favourable for evaporation of nectar and prevents microbial growth, whereas high humidity necessary for brood development is likely to be maintained only where it is important, i.e. within the cell. Hygroscopic cocoons that are incorporated into the cell walls could, based on our results, play an important role in buffering humidity fluctuations and may also influence thermoregulation (Klingner et al. 2005; Humphrey and Dykes 2008). However, the direct relationship between brood survivorship and a comb's ability to absorb and release water remains to be confirmed. Humidity should be measured within the cells to confirm whether it is indeed elevated above hive atmosphere, thus favouring brood development. Elucidating the water economy of the colony will allow further understanding of the complexity of nest homeostasis regulation in honeybees.

Acknowledgements We thank Mart-Mari Breedt for the programming and use of the custom-designed image analysis software, Dr. C. W.W. Pirk for advice on statistical analysis and T.J. Ellis for use of the photographic equipment. This work was supported by the University of Pretoria and the National Research Foundation of South Africa.

\section{References}

Berry JA, Delaplane KS (2001) Effects of comb age on honey bee colony growth and brood survivorship. J Apic Res 40:3-8

Büdel A (1948) Der Wasserdampfhaushalt im Bienenstock. Z Vgl Physiol 36:249-273

Chauvin G, Vannier G, Gueguen A (1979) Larval case and water balance in Tinea pellionella. J Insect Physiol 25:615-619

Danks HV (2002) Modification of adverse conditions by insects. Oikos 99:10-24

Dietz A, Haydak MH (1971) Caste determination in honey bees: I. The significance of moisture in larval food. J Exp Zool 177:353-358

Doull KM (1976) The effects of different humidities on the hatching of the eggs of honeybees. Apidologie 7:61-66
Ellis MB, Nicolson SW, Crewe RM, Dietemann V (2008) Hygropreference and brood care in the honeybee (Apis mellifera scutellata). J Insect Physiol 54:1516-1521

Hepburn HR (1986) Honeybees and wax. Springer, Berlin

Hepburn HR, Kurstjens SP (1988) The combs of honeybees as composite materials. Apidologie 19:25-36

Human H, Nicolson SW, Dietemann V (2006) Do honeybees, Apis mellifera scutellata, regulate humidity in their nest? Naturwissenschaften 93:397-401

Humphrey JAC, Dykes ES (2008) Thermal energy conduction in a honey bee comb due to cell-heating bees. J Theor Biol 250:194-208

Jay SC (1964) The cocoon of the honey bee, Apis mellifera L. Can Entomol 96:784-792

Klingner R, Richter K, Schmolz E, Keller B (2005) The role of moisture in the nest thermoregulation of social wasps. Naturwissenschaften 92:427-430

Lindauer M (1954) Temperaturregulierung und Wasserhaushalt im Bienenstaat. Z Vgl Physiol 36:391-432

Lyon BE, Cartar RV (1996) Functional significance of the cocoon in two arctic Gynaephora moth species. Proc R Soc Lond B 263:1159-1163

McNally LC, Schneider SS (1992) Seasonal cycles of growth, development and movement of the African honey bee, Apis mellifera scutellata, in Africa. Insect Soc 39:167-179

Nowbahari B, Thibout E (1990) The cocoon and humidity in the development of Acrolepiopsis assectella (Lep.) pupae: consequences in adults. Physiol Entomol 15:363-368

Otis GW, Wearing-Wilde JM (1992) Net reproductive rate of unmanaged colonies, (Apis mellifera L.). Insect Soc 39:157165

Otto C (1983) Behavioural and physiological adaptations to a variable habitat in two species of case-making caddis larvae using different food. Oikos 41:188-194

Reinhardt JF (1939) Ventilating the bee colony to facilitate the honey ripening process. J Econ Entomol 32:654-660

Ribbands CR (1953) The behaviour and social life of honeybees. Bee Research Association, London

Rudall KM (1962) Silk and other cocoon proteins. In: Florkin M, Mason HS (eds) Comp biochem. Academic, New York

Schneider S, Blyther R (1988) The habitat and nesting biology of the African honey bee Apis mellifera scutellata in the Okavango river delta, Botswana, Africa. Insect Soc 35:167-181

Tagawa J (1996) Function of the cocoon of the parasitoid wasp, Cotesia glomerata L. (Hymenoptera: Braconidae): protection against desiccation. Jap Soc App Entomol Zool 31:99-103

Winston ML, Dropkin JA, Taylor OR (1981) Demography and life history characteristics of two honey bee races (Apis mellifera). Oecologia 48:407-413

Wohlgemuth R (1957) Die temperaturregulation des Bienenvolkes unter Regeltheoretischen Gesichtspunken. Z Vgl Physiol 40:119161 